\title{
Purification and Partial Sequencing of the Major Mitogen for Human Uterine Smooth Muscle-like Cells in Leiomyoma Extracts
}

\author{
Antigone Sourla and Michael Koutsilieris \\ Molecular Endocrinology Laboratory, Research Center, Centre Hospitalier de l'Universite Laval (CHUL), Ste. Foy, \\ Quebec, G1V 4G2 Canada
}

\begin{abstract}
We purified the major mitogen for human smooth musclelike cells in leiomyoma extracts by sequential liquid chromatography on $(a)$ carboxymethyl-Sepharose, $(b)$ heparinSepharose columns, $(c)$ cartridges of $C_{18}$ silica, and $(d)$ linear gradient reverse-phase high performance liquid chromatography. The mitogenic activity of the leiomyoma extract throughout purification was tested by tritiated thymidine incorporation and DNA content in NIH/3T3 fibroblasts and KW human smooth muscle-like cells. Purification of the leiomyoma-derived growth factor (LDGF) for KW smooth muscle-like cells confirmed that its partial $\mathbf{N H}_{2^{-}}$ terminal amino acid (aa) sequence (1-20 aa) was identical to 113-132 aa of the human cysteine-rich protein (hCRP). A synthetic peptide which was engineered based on the purified aa sequence, stimulated the proliferation and growth of KW cells. An oligonucleotide probe constructed by the cDNA of the hcrp gene that encodes this aa sequence depicted the expression of 1.9-kb LDGF mRNA in leiomyomas and myometrium. The expression of the LDGF mRNA was three to sixfold higher in leiomyomas compared with adjacent myometrium of women harboring leiomyomas by in situ hybridization analysis. These data suggest that LDGF may participate in the pathophysiology of uterine leiomyomas. (J. Clin. Invest. 1995.96:751-758.) Key words: myometrium • leiomyomas • growth substances $\bullet$ cysteine-rich protein • smooth muscle cells
\end{abstract}

\section{Introduction}

Recently, several biologically active peptides, including ( $a$ ) metastasis-stimulating factor(s) from mouse uterus $(1,2) ;(b)$ rat, rabbit, and bovine uterus-derived growth factors $(3) ;(c)$ $17-\mathrm{kD}$ heparin-binding growth factor (HBGF-8) partially purified from bovine uterus similar to basic fibroblast growth factor (bFGF) (4); (d) mitogens(s) distinct from EGF in porcine uterus extracts $(5,6)$; and $(e)$ human uterine muscle-derived

Address correspondence to Michael Koutsilieris, Molecular Endocrinology Laboratory, Research Center, Centre Hospitalier de L'Universite Laval (C.H.U.L.), Ste. Foy, Quebec, G1V 4G2, Canada. Phone: 418654-2296; FAX: 418-654-2714.

Received for publication 11 August 1994 and accepted in revised form 13 April 1995.

J. Clin. Invest.

(C) The American Society for Clinical Investigation, Inc.

0021-9738/95/08/0751/08 \$2.00

Volume 96, August 1995, 751-758 and leiomyoma-derived growth factors (DGF) ${ }^{1}$ have been implicated in uterine physiology and pathophysiology (7-11). Growth factors, such as IGFs, EGF, PDGF, TGF $\beta$ s, bFGF, and their receptors, were postulated to play an important role in human uterine physiopathology (12-27), including leiomyomas $(15,16,19,24-27)$.

Our previous studies documented that uterine tissues contain mitogens and inhibitors for skin fibroblasts, osteoblasts, myoblasts, and rat aorta smooth muscle-like cells (7-9). Moreover, preferential mitogens for rat and mouse muscle-like cells were extracted from leiomyomas that were undetectable in myometrial and endometrial extracts $(10,11)$.

Herein we report the final purification and the partial amino acid (aa) sequence of an LDGF with preferential activity in KW human uterine smooth muscle-like cells. This material contained activity equivalent to IGF-I, and its $\mathrm{NH}_{2}$-terminal sequence (1-20 aa) encompassed part (113-132 aa) of the LIM motif (zinc finger) of human cysteine-rich protein (hCRP). Using a synthetic peptide comprising this amino acid sequence and an oligonucleotide probe synthetically engineered by the cDNA sequence that encodes this aa sequence, we confirmed that ( $a$ ) synthetic peptide is mitogenic for uterine smooth muscle cells, and $(b)$ there exists the expression of a discrete signal at 1.9-kb LDGF mRNA in uterine tissues. The expression of the LDGF mRNA was remarkably higher (three- to sixfold) in leiomyomas than in the adjacent myometrium of women harboring leiomyomas as detected by in situ hybridization analysis. These data suggest that this LDGF is possibly linked with the pathophysiology of uterine leiomyomas.

\section{Methods}

Source, handling of tissues, and extraction method. Uterine tissues were obtained at hysterectomy of premenopausal women harboring leiomyomas; these women had received no therapy before surgery. Leiomyoma tissues were carefully washed with ice-cold and serum-free HBSS and either extracted or stored at $-80^{\circ} \mathrm{C}$ without preservatives until use. Tissues were minced and extracted in $40 \mathrm{ml} / \mathrm{gram}$ of $50 \mathrm{mM}$ of ammonium acetate, $\mathrm{pH} 5.5$, containing $50 \mathrm{mg} /$ liter PMSF, $10 \mathrm{mg} /$ liter soybean trypsin inhibitor, and $1 \mathrm{mg} /$ liter aprotinin for $2 \mathrm{~h}$ at $4^{\circ} \mathrm{C}$ with agitation $(10,11)$. The extract was centrifuged at $10,000 \mathrm{~g}$ for $30 \mathrm{~min}$ and filtered with $0.45-\mu \mathrm{M}$ filters. The extract was dried and redissolved in DME/ F-12, and aliquots were tested for bioactivity and protein content ( 7 , 10,11 ). This study was approved by the local ethics committe (Laval University, Ste. foy, Canada) according to the guidelines of Medical

1. Abbreviations used in this paper: aa, amino acid; ACN, acetonitrile; CM-c, carboxymethyl-Sepharose chromatography; ELP, embryonal long terminal repeat-binding protein; hCRP, human cysteine-rich protein; HS-c, heparin-Sepharose chromatography; LDGF, leiomyoma-derived growth factor; rHPLC, reverse phase HPLC; SF-1, steroidogenic factor 1; TFA, trifluoroacetic acid. 
Research Council (MRC) of Canada for the use of human tissues in medical research.

Bioassay systems - mitogenic activity. The mouse NIH/3T3 fibroblasts were from the American Type Culture Collection (RL1658; ATCC, Bethesda MD), and the KW human uterine smooth musclelike cells were spontaneously propagated in a cell line after continuous subcultures of fast-growing cells isolated by enzymatic digestion from normal human uterine muscle (28). In our laboratory, the $\mathrm{KW}$ cell line was characterized to express phenotype compatible with human smooth muscle cells, including the expression of smooth muscle cell-specific alpha actin (29).

These cells were used as indicator bioassay systems to assess the mitogenic activity of leiomyoma fractions throughout purification. Cell lines were maintained in DME/F-12 containing $10 \%$ calf serum in 75 $\mathrm{cm}^{2}$ tissue culture flasks. When the cultures reached confluence, the cells were trypsinized using a mixture of $0.1 \%$ trypsin (Sigma Chemical Co.; St. Louis, MO) and $0.01 \%$ EDTA (Sigma Chemical Co.) in HBBS and precipitated by low-speed centrifugation. Then the cells were counted in a hemocytometer using trypan blue exclusion to assess viability and plated at $5 \times 10^{4}$ cells/well in 24-well plates using DME/F-12 medium containing $10 \%$ calf serum. After $24 \mathrm{~h}$, the cells were changed to serum-free medium for an additional $24 \mathrm{~h}$ and then stimulated with aliquots of the fractions under investigation $(7-11,29)$.

The rate of the tritiated thymidine incorporation was assessed by adding $2 \mu \mathrm{Ci}$ of tritiated thymidine (sp act; $20 \mathrm{Ci}$-mmol; ICN Radiochemicals, Boston, MA) to each well. The medium was aspirated and the cells washed twice with ice-cold PBS. Then $1 \mathrm{ml}$ of ice-cold trichloroacetic acid (10\% TCA) was added. The TCA-insoluble material was dissolved in $0.5 \mathrm{ml}$ of $0.6 \mathrm{~N} \mathrm{NaOH}$, and radioactivity $(\mathrm{cpm} / \mu \mathrm{g}$ DNA) was measured by liquid scintillation spectrometry $(7-11)$. The DNA content was also evaluated ( $\mu \mathrm{g}$ DNA/well) in monolayer cultures as previously described $(7-11,29)$. Mitogenic activity throughout purification was analyzed as units per microgram of protein; $1 \mathrm{U}$ was defined as the stimulation in tritiated thymidine incorporation and DNA content (percent above control) achieved by $10 \mathrm{ng} / \mathrm{ml}$ of IGF-I in the $\mathrm{KW}$ smooth muscle-like cells and NIH/3T3 fibroblasts. The cell number was counted by a hemocytometer using the trypan blue exclusion method in cell cultures treated with mitogens for 4 consecutive days $(7-11,29)$.

The results were expressed as percent above controls $=$ tritiated thymidine incorporation $(\mathrm{cpm} / \mu \mathrm{g}$ DNA), DNA content ( $\mu \mathrm{g}$ DNA well), and number of cells in cell cultures incubated with mitogens minus tritiated thymidine incorporation, DNA content, and number of cells in cell cultures without mitogens (controls), divided by the latter $\times 100$. Results were presented as mean value and standard error $(X \pm S E)$ in triplicate determinations. Statistical evaluation was by ANOVA (Dunnett's test)

Carboxymethyl (CM)-Sepharose chromatography (CM-c). CM-c was performed on a $12 \times 5.8 \mathrm{~cm}$ column preequilibrated with $50 \mathrm{mM}$ ammonium acetate, $\mathrm{pH} 5.5$, at $4^{\circ} \mathrm{C}$. The flow rate was $200 \mathrm{ml} / \mathrm{h}$. Leiomyoma extracts were first loaded on the column and then washed by 50 $\mathrm{mM}$ ammonium acetate, $\mathrm{pH} 5.5$. CM-c was eluted by $1.2 \mathrm{M} \mathrm{NaCl}$ (onestep elution) as previously described (11).

Heparin-Sepharose chromatography (HS-c). HS-c was performed on a $1.6 \times 18 \mathrm{~cm}$ column preequilibrated with $20 \mathrm{mM}$ Tris- $\mathrm{HCl}$ containing $0.6 \mathrm{M} \mathrm{NaCl}, \mathrm{pH} 7.1$, at $4^{\circ} \mathrm{C}$. The flow rate was $50 \mathrm{ml} / \mathrm{h}$. The protein fractions eluted from CM-c were diluted using Tris $20 \mathrm{mM}, \mathrm{pH}$ 7.1 , to $0.6 \mathrm{M} \mathrm{NaCl}$ and adjusted to $\mathrm{pH} 7.1$ using $1 \mathrm{M}$ Tris- $\mathrm{HCl}$. These fractions were then loaded onto HS-c and eluted by $2.0 \mathrm{M} \mathrm{NaCl}$ (onestep elution). Eluates were analyzed by SDS-PAGE as previously described (30).

Fractionation over cartridges of $C_{18}$ silica. Fractions eluted from the HS-c were diluted with 1 vol of $0.1 \%$ trifluoroacetic acid (TFA) and then loaded onto cartridges of octadecylsilyl (ODS) silica $\left(\mathrm{C}_{18}\right.$ SepPak; Water Associates, Mississauga, Canada) preactivated by acetonitrile (ACN) $(80 \% \mathrm{ACN} / 0.1 \% \mathrm{TFA})$. As a result, three solutions were generated: $(a)$ pass through containing proteins not retained onto car- tridges of $\mathrm{C}_{18}$ silica; $(b)$ wash containing proteins and salts washed out by the $0.1 \%$ TFA; and $(c)$ eluate containing the proteins retained on Sep-Pak and eluted by $80 \%$ ACN in $0.1 \%$ TFA (31). The eluted proteins were analyzed by SDS-PAGE and tested for mitogenic activity.

Reverse-phase HPLC ( $r H P L C)$. The material eluted from cartridges of $\mathrm{C}_{18}$ silica was redissolved in $0.1 \%$ TFA and further purified using linear gradient elution (linear gradient, 12-60\% ACN) (see Fig. 4). The HPLC system was composed of two pumps (model 510, Waters Associates), an automatic gradient controller, and an LKB 2221 recording integrator. Eluates were monitored by ultraviolet absorbance at $214 \mathrm{~nm}$ using a wavelength flow-through spectrophotometer (HPLC System model 441; Waters Associates) and rHPLC was performed on $\mathrm{C}_{18} \mu$ Bondapak column $(3.9 \times 300 \mathrm{~mm}$; Waters Associates $)$ at a flow rate of $1.0 \mathrm{ml} / \mathrm{min}$ using linear gradients of acetonitrile containing 0.1 TFA as a counter ion as previously described $(31,32)$. The eluted fractions were collected using a Redirac LKB fraction (Pharmacia, Montreal, Canada) collector ( $3 \mathrm{~min}$ collection $=3 \mathrm{ml}$ ), and aliquots were tested for mitogenic activity in indicator bioassay systems. The eluted material was analyzed by SDS-PAGE electrophoresis.

Amino acid sequence analysis and peptide synthesis. Sequence analysis was performed at Clinical Research Institute of Montreal, Montreal, Canada, using a gas-phase sequenator (model 470A; Applied Biosystems, Inc., Foster City, CA) directly coupled to a phenylthiohydantoin (PTH)-analyzer (model 120A; Applied Biosystems, Inc.) as previously described (33). The PTH-amino acid yield for each cycle was normalized according to a PTH-Norleucine standard added directly before separation; the initial and repetitive yields were obtained by linear regression from the yields of selected stable PTH derivatives (33). The synthetic peptides were engineered by the solid phase method at Sheldon Biotechnology Center, McGill University, Montreal, Canada. These synthetic peptides were purified by rHPLC and characterized by amino acid analysis and mass spectra analysis.

Extraction of total RNA and Northern analysis. Leiomyomal and myometrial total RNA was extracted from tissues obtained at surgery from premenopausal women harboring leiomyomas; these women had received no therapy before hysterectomy. From each hysterectomy, we extracted leiomyomal and myometrial total RNA using an acid guanidinium thiocyanate, phenol, and chlorophorm extraction procedure (34). The samples of total RNA $(10 \mu \mathrm{g})$ were electrophoresed through formaldehyde-agarose slab gels, transferred to GeneScreen Plus, and hybridized overnight with $10^{6} \mathrm{cpm} / \mathrm{ml}$ probe at $42^{\circ} \mathrm{C}$ in a buffer containing 5 $\times$ SSPE ( $750 \mathrm{mM} \mathrm{NaCl}, 50 \mathrm{mM} \mathrm{NaH}_{2} \mathrm{PO}_{4}, \mathrm{pH} 7.6,5 \mathrm{mM} \mathrm{Na}_{2}$ EDTA), $50 \%$ formamide, $5 \times$ Denhardt's, and $2 \%$ SDS. Membranes were washed in $2 \times$ SSPE, $2 \%$ SDS at $65^{\circ} \mathrm{C}$ for $30 \mathrm{~min}$. Membranes were autoradiographed at $-70^{\circ} \mathrm{C}$ with Fisher Biotech intensifying screens (Fisher, Pittsburgh, PA) for various times, depending on the signal intensities. Quantification of the band intensities was carried out using a PhosphorImager, and data were analyzed using ImageQuant Software v3.0 (Molecular Dynamics, Inc., Sunnyvale, CA). The probes were stripped from the membranes by heating to $95^{\circ} \mathrm{C}$ in $10 \mathrm{mM}$ Tris, $\mathrm{pH}$ $7.5,1 \%$ SDS for $20-30 \mathrm{~min}$ before rehybridization with another probe. The oligonucleotide probe ( 5 '-CACCTTCTCCGCAGCATAGACTGCCTGGCTGCATCGGGGGCAGCGCTCGGAGCCACCAAT-3') was synthetically engineered based on the nucleotide sequence of the hcrp gene, which encodes the 113-132 aa (35). Labeling was by the random primer method using the kit from Boehringer Mannheim Biochemicals (Indianapolis, IN), ${ }^{32} \mathrm{P}$ from Amersham Corp. (Arlington Heights, IL), and GeneScreen Plus membranes from Dupont (Montreal, Canada).

In situ hybridization. We decided to analyze leiomyomal and myometrial tissues from four women who underwent hysterectomy while in the proliferative phase (phase I of the menstrual cycle). The phase of 'menstrual cycle was confirmed by the endometrial histology. The leiomyomal and myometrial tissues were embedded in $10.24 \%(\mathrm{wt} / \mathrm{wt})$ polyvinyl alcohol, $4.26 \%$ (wt/wt) polyethelene glycol, and $85.5 \%$ (wt/ $\mathrm{wt}$ ) nonreactive ingredient-embedding medium for frozen tissue specimens (Miles Inc., Elkhart, IN) and mounted on a cryostat. Serial sections were cut $(10 \mathrm{~mm}$ thick $)$ at $-16^{\circ} \mathrm{C}$, collected on poly-L-lysine- 
Figure 1. The mitogenic activity of leiomyoma extract throughout purification. Mitogenic activity was expressed as units of mitogenic activity per milligram of protein (U/ $\mu \mathrm{g}$ protein). (A) Mitogenic activity in crude extract; $(B)$ in the eluates of CM-c; $(C)$ in the eluates of HS-c; $(D)$ in the eluates of Sep-Pak; and $(E)$ in the eluates of rHPLC. Mitogenic activity was assessed in $\mathrm{KW}$ human uterine smooth muscle-like cells (-) and in NIH/3T3 fibroblasts ( $\square) .1 \mathrm{U}$ of activity was defined as the stimulation of $10 \mathrm{ng} / \mathrm{ml}$ of IGF-I expressed as percent above controls in these indicator cell cultures (see Methods).

coated slides, and stored at $-80^{\circ} \mathrm{C}$. Tissue sections were fixed for 20 $\min$ in $4 \%$ paraformaldehyde $(\mathrm{wt} / \mathrm{vol})$ at $4^{\circ} \mathrm{C}$ and then washed in 0.1 M phosphate buffer for $20 \mathrm{~min}(4 \times 5 \mathrm{~min}$ each $)$. Before hybridization the sections were washed first in $2 \times$ SSC solution $(0.3 \mathrm{M}$ sodium chloride and $0.03 \mathrm{M}$ sodium citrate) and then in a $2 \times$ SSC solution containing $0.1 \%$ Triton X-100 for 10 and $20 \mathrm{~min}$, respectively. Prehybridization was performed in a buffer solution containing $50 \%$ (vol/ vol) formamide, $5 \times \operatorname{SSPE}(20 \times \operatorname{SSPE}=0.18 \mathrm{M} \mathrm{NaCl}, 10 \mathrm{mM}$ $\mathrm{NaH}_{2} \mathrm{PO}_{4}, 1 \mathrm{mM}$ EDTA, pH 7.4, 0.1\% SDS, $0.1 \%$ [wt/vol] polyvinylpyrrolidone, $200 \mu \mathrm{g} / \mathrm{ml}$ denaturated salmon testis DNA, $2 \mu \mathrm{g} / \mathrm{ml}$ poly $(\mathrm{A})^{+} \mathrm{RNA}, 4 \%$ [wt/vol] dextran sulfate, and $10 \mathrm{mM} \mathrm{DTT}$ ) at $39^{\circ} \mathrm{C}$ for $2 \mathrm{~h}$.

The ${ }^{35} \mathrm{~S}$-labeled oligonucleotide probe was prepared by a typical tailing reaction using terminal deoxynucleotidyltransferase (TdT; 25 $\mathrm{U} / \mu \mathrm{l})$ and $\left[\alpha^{-35} \mathrm{~S}\right]$-labeled ATP $(100 \mu \mathrm{Ci} / 100 \mu \mathrm{l}$; Amersham Corp. purified on NAP-sephadex G25 DNA grade column (Pharmacia LKB Biotechnology Inc, Piscataway, NJ). Two million counts of this labeled oligonucleotide probe (5'-CACCTTCTCCGCAGCATAGACTGCCTGGCTGCATCGGGGGCAGCGCTCGGAGCCACCAAT-3', synthetically engineered as described above) was diluted in the prehybridization buffer, and hybridization was performed at $39^{\circ} \mathrm{C}$ for $16 \mathrm{~h}$. After hybridization the slides were washed at $20^{\circ} \mathrm{C}$ in $(a) 2 \times$ SSC solution for $40 \mathrm{~min}$; (b) $1 \times \mathrm{SSC}$ solution for $40 \mathrm{~min}$; and (c) $0.5 \times \mathrm{SSC}$ solution $\times 2$ for $40 \mathrm{~min}$ each at $20^{\circ} \mathrm{C}$ and $39^{\circ} \mathrm{C}$, respectively. The slides were rinsed with ascending concentrations of ethanol 70, 90, and $100 \%$ and air-dried. The slides were exposed to film (Eastman Kodak Co., Rochester, NY) for $7 \mathrm{~d}$, and the intensity of the signals was analyzed as described above (Northern analysis). The sections were coated with a Kodak NTB-2 liquid photographic emulsion diluted 1:1 with distilled water at $45^{\circ} \mathrm{C}$ and stored in darkness at $4^{\circ} \mathrm{C}$. After 5 and $7 \mathrm{~d}$ of exposure, the slides were developed and stained with hematoxylin and eosin $(\mathrm{H} /$ E). The slides used as negative controls (RNase) were pretreated with ribonuclease $A(10 \mathrm{mg} / \mathrm{ml})$ and ribonuclease $T(100,000 \mathrm{U} / \mathrm{ml})$ in 2 $\times \mathrm{SSC}$ for $45 \mathrm{~min}$ at $39^{\circ} \mathrm{C}$. Signal intensity $\left(\mathrm{OD} / \mathrm{mm}^{2}\right)$ was evaluated by subtracting the RNase signal from each individual signal measurement in leiomyoma (L) and myometrium (M) tissues. The results were expressed as ratio of L/M signal intensity in tissues from each hysterectomy (relative expression of hCRP mRNA).
Table I. Purification of the Leiomyoma-derived Mitogen for Human KW Uterine Smooth Muscle-like Cells

\begin{tabular}{lccr}
\hline Purification step & Protein content & Activity & Purification \\
\hline & $\mu g$ & $U / \mu g^{*}$ & \multicolumn{1}{c}{ fold } \\
Crude extract & $34.39 \times 10^{6}$ & 0.004 & - \\
CM-c & $4.64 \times 10^{6}$ & 0.02 & 5 \\
HS-c & $14.16 \times 10^{3}$ & 0.3 & 75 \\
Sep-PAK & 683 & 6.25 & $1,562.5$ \\
rHPLC & 20 & 124.000 & $31,000.0$ \\
& & & \\
\hline
\end{tabular}

* $1 \mathrm{U}$ of mitogenic activity = the stimulation of $10 \mathrm{ng} / \mathrm{ml}$ of IGF-1 in the DNA synthesis of KW smooth muscle-like cells expressed as percent above control (see Methods).

\section{Results}

Leiomyoma tissue (wet weight, $2.56 \mathrm{~kg}$ ) was extracted as described in Methods. Extracts contained 34.39 grams of total protein; aliquots of $50-250 \mu \mathrm{g} / \mathrm{ml}$ stimulated tritiated thymidine incorporation and DNA content in $\mathrm{KW}$ smooth muscle cells and NIH/3T3 fibroblasts in a dose-dependent manner, confirming our previous findings (7-11). Leiomyoma extracts contained higher activity in fibroblasts than in smooth muscle cells. The leiomyoma extract contained $0.004 \mathrm{U} / \mu \mathrm{g}$ of activity in $\mathrm{KW}$ smooth muscle-like cells and $0.02 \mathrm{U} / \mu \mathrm{g}$ in NIH/3T3 cells (Fig. $1 A$ ).

The leiomyoma extract was further purified onto CM-c as described in Methods. The eluted proteins from the CM-c also contained mitogens for both the fibroblasts and smooth musclelike cells. The CM-c eluates contained $0.02 \mathrm{U} / \mu \mathrm{g}$ of activity in $\mathrm{KW}$ cells and $0.008 \mathrm{U} / \mu \mathrm{g}$ in NIH/3T3 fibroblasts, indicating that CM-c purified by fivefold the leiomyomal mitogen(s) in $\mathrm{KW}$ cells. In contrast, the CM-c eluates contained less activity in NIH/3T3 fibroblasts compared with crude leiomyoma extracts (Fig. $1 B$ ). These data suggest that important mitogen(s) for fibroblasts possibly passed through CM-c under these experimental conditions. Indeed, compared with the eluted fractions from CM-c, the pass-through fractions contained twice as much mitogenic activity $(0.017 \mathrm{U} / \mu \mathrm{g})$ in fibroblasts.

The CM-c eluates were diluted and rechromatographed on HS-c as described in Methods. The fractions eluted from heparin-Sepharose contained $0.3 \mathrm{U} / \mu \mathrm{g}$ mitogenic activity in $\mathrm{KW}$ cells and $0.2 \mathrm{U} / \mu \mathrm{g}$ in NIH/3T3 fibroblasts (Fig. $1 C$ ), $\sim 75-$ fold purification in the KW cell-specific activity (Table I).

The HS-c eluates were fractionated using cartridges of $\mathrm{C}_{18}$ silica as described in Methods. Eluted material contained 6.25 $\mathrm{U} / \mu \mathrm{g}$ mitogenic activity in $\mathrm{KW}$ smooth muscle-like cells and $0.28 \mathrm{U} / \mu \mathrm{g}$ in NIH/3T3 fibroblasts (Fig. $1 D$ ). This step contributed to $1,562.5$-fold purification of the mitogen $(s)$ in smooth muscle-like cells and 14-fold purification in NIH/3T3 cells, suggesting purification of preferential mitogen(s) for human smooth muscle cells $(8,10,11)$.

We further purified the smooth muscle cell-specific activity using linear gradient rHPLC (Fig. 2). Aliquots containing 75 $\mathrm{ng} / \mathrm{ml}$ of the peptide(s) eluted by $35 \%$ of $\mathrm{ACN}$ in a linear HPLC gradient (28-44\% ACN in $0.1 \%$ TFA within $40 \mathrm{~min}$ ) equivalently stimulated $\mathrm{KW}$ smooth muscle-like cells with 100 $\mathrm{ng} / \mathrm{ml}$ of IGF-I (Fig. 2). This material was less active in NIH/ 

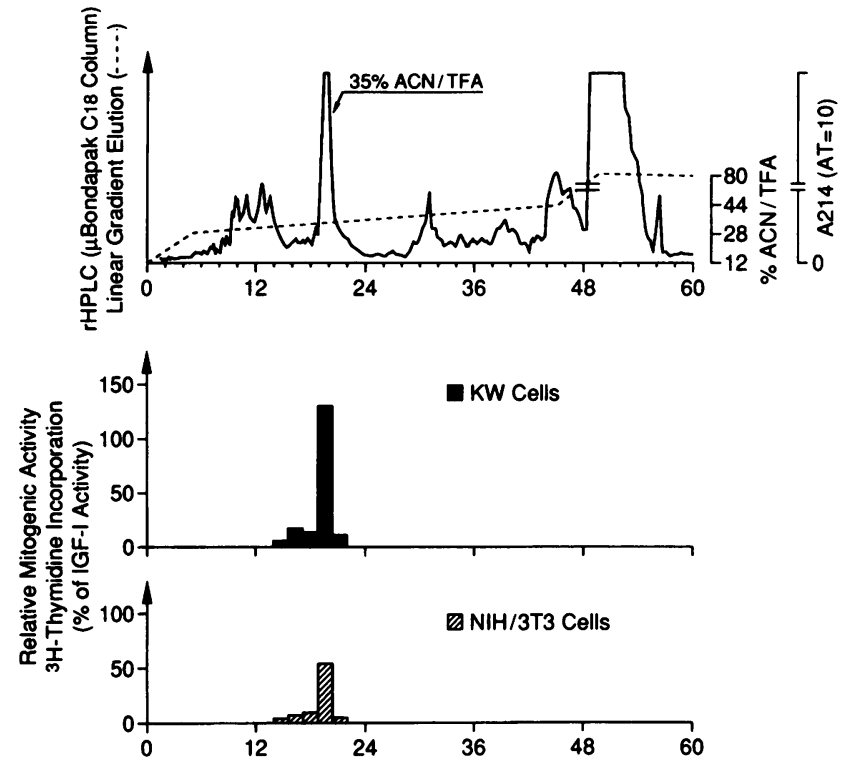

Figure 2. Purification of the eluates of Sep-Pak by rHPLC. (Upper panel) ultraviolet $\left(A_{214}-\right)$ profile of the proteins eluted from $\mathrm{mBon}$ dapak C18 column using a linear HPLC gradient (---) of ACN over $0.1 \%$ TFA. (Middle panel) Mitogenic activity of the rHPLC eluates in $\mathrm{KW}$ smooth muscle-like cells. (Lower panel) Mitogenic activity of the rHPLC eluates in NIH/3T3 fibroblasts. Aliquots of the protein eluted by $35 \%$ ACN/TFA (containing 75 ng of protein as estimated later by sequence analysis) stimulated preferentially smooth muscle-like cells. The relative mitogenic activity of this material was at least as mitogenic as IGF-I ( $\mathrm{ng} / \mathrm{ng}$ ) in $\mathrm{KW}$ cells. In contrast, in NIH/3T3 cells, this material contained $\sim 50 \%$ of IGF activity.

3T3 cells (Fig. 2, middle and lower panels). An additional step of rHPLC using the same linear gradient finally purified $\sim 20$ $\mu \mathrm{g}$ of this active material (LDGF for smooth muscle-like cells ). Increasing doses $(0.5-75 \mathrm{ng} / \mathrm{ml})$ of the LDGF stimu-

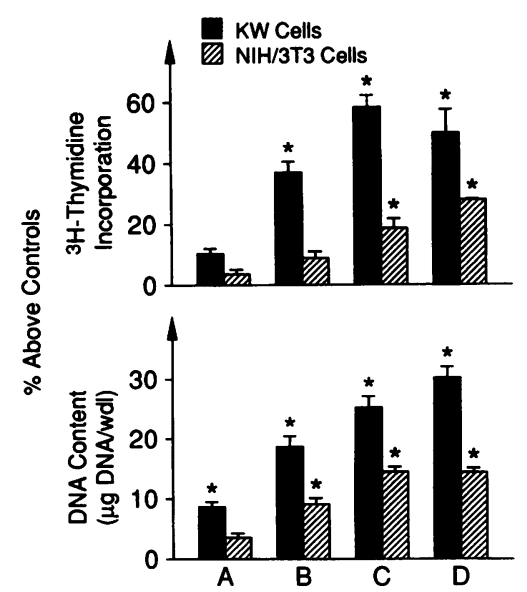

Figure 3. Mitogenic activity of the material purified by rHPLC. The effects of $A=0.5 ; B=10$; and $C=75 \mathrm{ng} / \mathrm{ml}$ in $\mathrm{KW}$ cells $(\boldsymbol{a})$ and in NIH/3T3 fibroblasts (a) as assessed by the tritiated thymidine incorporation (top) and in DNA synthesis (bottom). The effects of $75 \mathrm{mg} / \mathrm{ml}$ of IGF-I in these indicator cell culture systems are presented in $D$. Results are expressed as percent above controls as described in Methods. Note that the mitogenic effects of this material were tested in cell cultures grown in serum-free DME/F-12 medium. Control levels of tritiated thymidine incorporation in KW cells were $=15,376 \pm 849$ and in $\mathrm{NIH} /$ $3 \mathrm{~T} 3$ cells $=27,345 \pm 2,513(\mathrm{X} \pm \mathrm{SE})$. Control level of DNA content in $\mathrm{KW}$ cells was $=2.2 \pm 0.08$ and in $\mathrm{NIH} / 3 \mathrm{~T} 3$ cells $=4.9 \pm 0.19(\mathrm{X} \pm \mathrm{SE})$ in triplicate determinations. $* P<0.01$. $\mathrm{X}$, mean value.

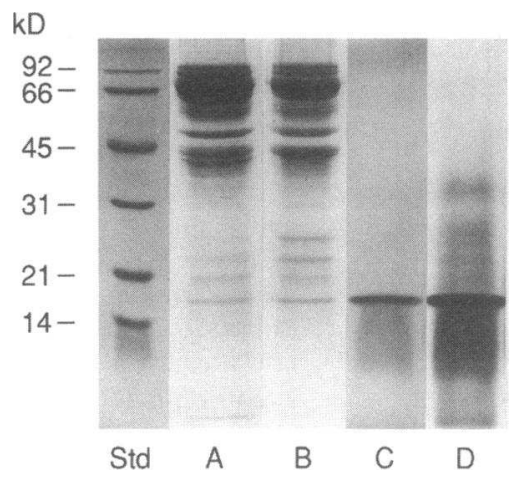

Figure 4. Analysis of purified proteins by $\mathrm{CM}-\mathrm{c}$ (lane $A$ ), HS-c (lane $B$ ) Sep-Pak (lane $C$ ), and rHPLC (lane $D$ ) as detected by SDS-PAGE electrophoresis using Commassie blue staining. Lane $D$ presents similar analysis by silver staining.

lated tritiated thymidine incorporation and DNA content of KW cells in a dose-dependent manner (Fig. 3). Evaluating the mitogenic activity as units per microgram, we calculated overall purification by 31,000 -fold (Table I). By SDS-PAGE, we analyzed the proteins eluted by the HS-c, cartridges of $\mathrm{C}_{18}$ silica, and the linear rHPLC gradient; the latter (LDGF) was a 17- to 18-kD protein (Fig. 4).

Sequence analysis confirmed final purification revealing a partial $\mathrm{NH}_{2}$-terminal aa sequence of the putative LDGF (1-20 aa) identical to 113-132 aa of the hCRP, encompassing part of the second zinc-finger "LIM motif", defined by $\mathrm{C}-\mathrm{X}_{2}-\mathrm{C}$ $\mathrm{X}_{17}-\underline{\mathrm{H}}-\mathrm{X}_{2}-\underline{\mathrm{C}}$ ( Cys-Pro-Arg-Cys-Ser-Gln-Ala-Val-Tyr-Ala-AlaGlu-Lys-Val-lle-Gly-Ala-Gly-Lys-Ser-Trp-His-Lys-Ala-Cys) (35). The complete zinc-finger region is encoded by exons 4 and 5 of hCRP cDNA (Table II).

To investigate whether the mitogenic activity of purified extracts is linked to the obtained aa sequence, we synthetically engineered three peptides encompassing $(a)$ peptide $\mathrm{A}$, part of the $\mathrm{NH}_{2}$-terminal of hCRP $(1-10 \mathrm{aa}) ;(b)$ peptide $\mathrm{B}$, the obtained aa sequence identical to $113-137$ aa sequence of hCRP; and $(c)$ peptide $\mathrm{C}$, part of the $\mathrm{COOH}$-terminal sequence of hCRP (170-193 aa). These peptides were tested for mitogenic activity by analyzing the $\left[{ }^{3} \mathrm{H}\right]$ thymidine incorporation, DNA content, and cell number in KW smooth muscle-like cells. Peptide B stimulated only the proliferation and growth of KW cells (Table III). The mitogenicity of the peptide B was comparable to this of purified leiomyoma extracts, thus definitely confirming that this aa sequence was a link to the putative LDGF in leiomyoma extracts.

To assess the corresponding size of the LDGF mRNA in uterine tissues, we extracted the total mRNA of leiomyoma and myometrium, which was further analyzed by Northern blots. For this analysis, we used the radiolabeled oligonucleotide probe synthetically engineered as described in Methods. This probe was engineered based on the cDNA sequence that encodes the $\mathrm{NH}_{2}$-terminal aa sequence of the LDGF. Northern analysis documented the presence of a discrete signal band of 1.9-kb LDGF mRNA (Fig. 5), which corresponded also to the expected size of hCRP mRNA (35).

Analysis of the relative expression of the LDGF mRNA depicted by this oligonucleotide probe in uterine tissues $(n$ $=4$; leiomyoma vs adjacent myometrium of the same uterus) documented a three- to sixfold higher mRNA expression in leiomyoma $(\mathrm{L})$ than in myometrium $(\mathrm{M})$ by in situ hybridization (L/M: $A=6$-fold; $B=6$-fold; $C=4.5$-fold; and $D=3$ fold; Figs. 6 and 7). 
Table II. The Amino Acid Sequence of the Purified Material (LM) and hCRP;* and the Nucleotide Sequence of the hcrp Gene which Encodes this Peptide Sequence

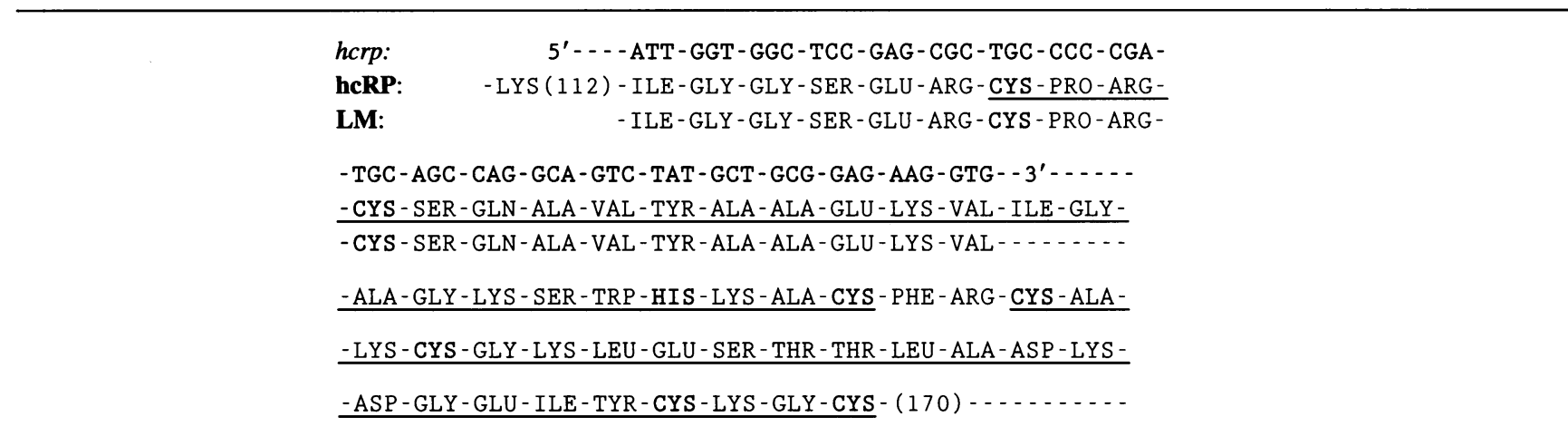

* The zinc-finger region "LIM motif' $\left(\mathrm{C}_{2} \mathrm{HC}-\mathrm{XX}-\mathrm{C}_{4}\right)$ of the hCRP amino acid sequence is underlined. Cysteine cannot be detected by sequence analysis.

\section{Discussion}

Although the effects of sex steroid hormones on the development, growth, and evolution of uterine leiomyomas are unquestionable, the mechanism of this action is unclear $(36,37)$. Recently, the presence of growth substances in normal and neoplastic uterine tissues was documented $(1-11,38)$, implicating growth substances as mediators of the effects of sex steroid hormones in the physiopathologic aspects of this tissue, including leiomyomas ( 38 and references therein).

Our previous studies established that $(a)$ myometrial and leiomyomal extracts contain mitogen( $s$ ) of a proteinaceous nature $(7) ;(b)$ cartridges of $C_{18}$ silica effectively retain these mitogens $(8,9)$; and $(c)$ mitogens are retained and can be eluted from CM-c and HS-c $(10,11)$. Herein we report the final purification of the LDGF for human smooth muscle-like cells using a purification scheme that used sequential liquid chromatography on CM-c, HS-c, cartridges of $\mathrm{C}_{18}$ silica, and $\mu$ Bondapak $\mathrm{C}_{18}$ rHPLC column. The mitogenic activity of LDGF throughout purification was assessed in the KW smooth

Table III. Comparable Mitogenic Activity of the Synthetic Peptide Containing the $\mathrm{NH}_{2}$-terminal Sequence of the Purified LDGF to Purified Leiomyoma Extracts in KW Smooth Muscle-like Cells

\begin{tabular}{lccc}
\hline & $\left.{ }^{3} \mathrm{H}\right]$ thymidine & DNA content & Cell number \\
\hline Synthetic peptide $(\mathrm{ng} / \mathrm{ml})$ & & & \\
0.1 & $12.8^{*}$ & 1 & - \\
0.5 & $27.5^{*}$ & 5 & - \\
1.0 & $35.7^{*}$ & $15.5^{*}$ & $16^{*}$ \\
100 & $32.1^{*}$ & $19.8^{*}$ & $20^{*}$ \\
1,000 & $10.2^{*}$ & $12.5^{*}$ & $8^{*}$ \\
$\begin{array}{l}\text { Purified extracts }(\mathrm{ng} / \mathrm{ml}) \\
1.0\end{array}$ & $24.5^{*}$ & $21.8^{*}$ & $18^{*}$ \\
& & & \\
\hline
\end{tabular}

Mitogenic activity was expressed as percent above controls as described in Methods: $\left[{ }^{3} \mathrm{H}\right]$ thymidine incorporation, control $=4,845 \pm 859(\mathrm{cpm} /$ $\mu \mathrm{g}$ DNA); DNA content: controls $=1,639 \pm 0.03$ ( $\mu \mathrm{g} \mathrm{DNA} /$ well); and cell number: controls $=7,774 \pm 547$. ${ }^{*} P<0.001$. muscle-like cells and NIH/3T3 fibroblasts, thus selecting for further purification the preferential activity for human uterine smooth muscle-like cells (KW cells). This method of screening for selective mitogens enabled us to identify protein fractions that were otherwise unidentifiable $(10,11,29)$.

Indeed, we purified a LDGF that stimulated the DNA content and tritiated thymidine incorporation of KW human smooth muscle-like cells. The activity of this LDGF was equivalent to IGF-I. Chemical analysis revealed that the $\mathrm{NH}_{2}$-terminal amino acid sequence of LDGF (1-20 aa), which was identical to 113-132 aa of the hCRP, a protein sequence predicted by the fortuitous isolation of $h c r p$ cDNA (35). The mRNA of hCRP was identified by screening a placental cDNA library at low stringency conditions with a human prolactin cDNA probe. Despite this, its structure and the predicted protein suggested a lack of evolutionary or functional relationship to human prolactin. Therefore, isolation of hcrp cDNA was based on limited sequence homology (35). hCRP is of unknown function, comprises $23.4 \mathrm{kD}$, and contains two copies of a domain encompassing an unusual double zinc-finger referred to as LIM motif (35). hCRP has a high degree of similarity to cysteine-rich rat and mouse intestinal protein (CRIP), a $8.5-\mathrm{kD}$ protein of unknown function. In contrast to hCRP, CRIP contains a single copy of this double zinc finger $\left(\underline{\mathrm{C}}-\mathrm{X}_{2}-\underline{\mathrm{C}}-\mathrm{X}_{17}-\underline{\mathrm{H}}-\mathrm{X}_{2}-\underline{\mathrm{C}}\right)-\mathrm{X}_{2}-(\underline{\mathrm{C}}-$ $\mathrm{X}_{2}-\mathrm{C}-\mathrm{X}_{17}-\mathrm{C}-\mathrm{X}_{2}-\mathrm{C}$ ) region (39). There is now evidence that other proteins contain a similar motif $\left(\underline{\mathrm{C}}-\mathrm{X}_{2}-\underline{\mathrm{C}}-\mathrm{X}_{11-30}-\underline{\mathrm{H}}-\mathrm{X}_{2}-\underline{\mathrm{C}}\right)$ $\mathrm{X}_{2}-\left(\underline{\mathrm{C}}-\mathrm{X}_{2}-\underline{\mathrm{C}}-\mathrm{X}_{10-18}-\underline{\mathrm{C}}-\mathrm{X}_{2}-\underline{\mathrm{C}}\right)(40,41$, and references therein $)$. It is noteworthy that a similar double zinc-finger motif was

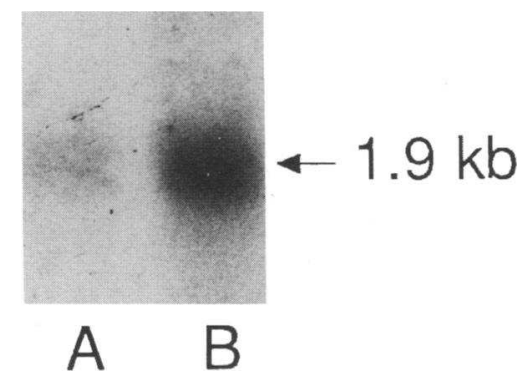

Figure 5. An example of the discrete signal produced by the labeled oligonucleotide probe that detected a 1.9-kb mRNA size in leiomyoma $(B)$ and normal myometrium $(A)$ as grossly assessed by Northern blot using as reference the elution position of 18S mRNA. 


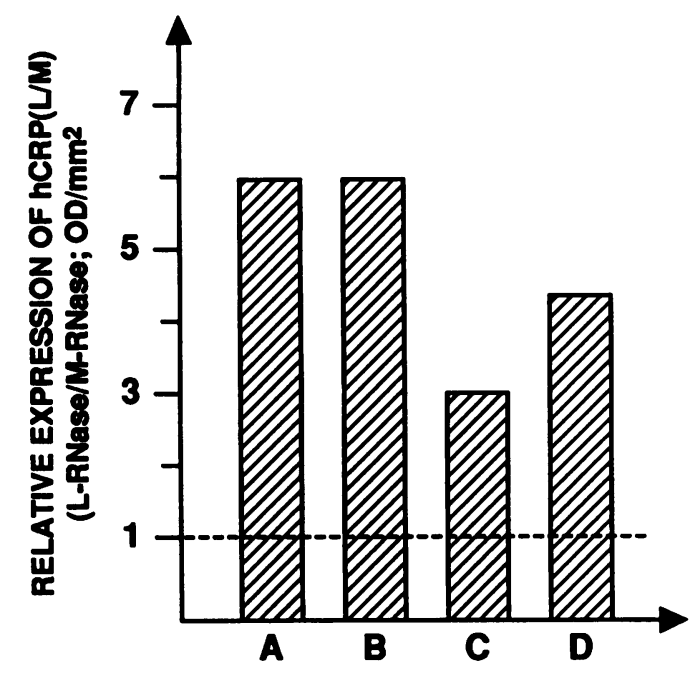

Figure 6. Relative expression of mRNA in leiomyomas versus myometrium as depicted by the labeled oligonucleotide probe using in situ hybridization. Signal density was analyzed as described in the Methods section. Results were expressed as the ratio of leoimyoma/myometrium ( $L / M$ ) expression of mRNA (relative expression). Leoimyoma tissues contained three to sixfold higher expression than normal myometrium in each individual uterus. The uterine tissues (4) were all from women at the same phase of the menstrual cycle (phase I).

also predicted in the protein sequence of an estrogen-stimulated cDNA isolated from rat C6 glioma cells (rESP1) (42).

The biologic importance of the double zinc-finger motif (hCRP-like) or single-finger (cysteine-rich rat and mouse intestinal protein-like) proteins is still unknown. The zinc finger is suggestive of an ability to bind DNA and RNA, possibly acting as transcriptional factors and is also suggestive of an ability to bind zinc ion and iron-sulfur clusters (35). It is interesting that hCRP is the product of an immediate response gene with an expression profile parallel to $c$-myc. The coordinate regulation of hcrp and $c$-myc suggests that these genes respond to the same regulatory pathways and may share transcription control features during the $G_{0}$ to $S$ transition. Although it is not clear that the shared LIM/double-finger domain dictates a commonality of function for this family of proteins, hCRP was the first to be identified as a primary response gene and thus possesses apparent biologic significance (40).

To definitely link the obtained amino acid sequence with the putative LDGF in leiomyoma extracts and to test the possible relationship with hCRP, we synthetically engineered three peptides comprising ( $a$ ) part of the $\mathrm{NH}_{2}$-terminal of hCRP; $(b)$ the purified $\mathrm{NH}_{2}$-terminal of LDGF; and (c) part of the $\mathrm{COOH}$ terminal of hCRP. Analysis of mitogenic activity documented that the synthetic peptide that corresponded to the $\mathrm{NH}_{2}$-terminal sequence of purified material stimulated only the proliferation $\left(\left[{ }^{3} \mathrm{H}\right]\right.$ thymidine incorporation) and cell growth (DNA content and cell number) of KW smooth muscle-like cells. Therefore, sequence analysis was on the putative LDGF in leiomyoma extracts. Because this synthetic peptide and aliquots of the purified leiomyoma extracts were mitogenic in $\mathrm{KW}$ cells grown in serum-free medium or culture medium containing limited calf serum $(0.5 \%)$, it is conceivable that LDGF is a growth factor enabling smooth muscle cells to enter from the $G_{0} / G_{1}$ phase to the $S$ phase of the cell cycle. This is compatible with the proposed role of products of various early response genes such as $c$-myc and hcrp (40).

Because the oligonucleotide probe used in our study detected threefold up to sixfold higher LDGF mRNA expression in leiomyomas compared with adjacent myometrium in the proliferative phase of the menstrual cycle, we believe that LDGF is probably the major mitogen for smooth muscle cells in uterine leiomyomas. Moreover, this oligonucleotide probe hybridized with a 1.9-kb mRNA similar to the expected hCRP mRNA size, suggesting that limited proteolysis of hCRP possibly generates the LDGF in leiomyoma tissues. It is noteworthy that the posi-
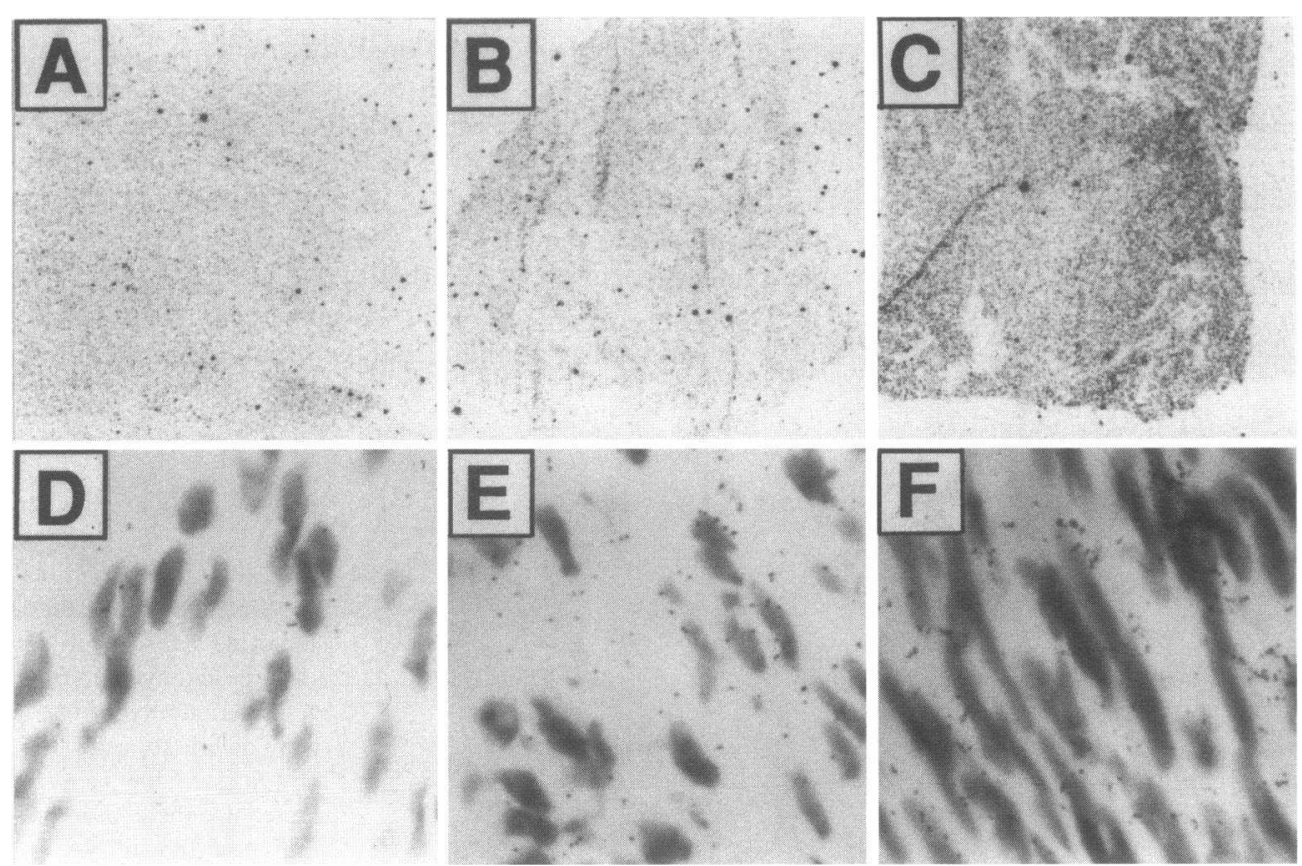

Figure 7. An example of the signal density obtained by in situ hybridization using the synthetically engineered radioactive oligonucleotide probe (details in the Methods section). Analysis was in leiomyoma ( $C$ and $F$ ), normal myometrium ( $B$ and $E$ ), and RNase-treated uterine tissues ( $A$ and $D$ ) of the same uterus (hysterectomy No. 45). The histology sections $(D-F)$ are presented at a magnification of 800 . 
tion 112-113 (Lys-Ile) of hCRP corresponding to the start of the $\mathrm{NH}_{2}$-terminal sequence of purified LDGF is a potential site for trypsin-like and endopeptidase lysine C-like enzyme action. In this context, the assessment of possible overexpression of hCRP (product of an early response gene leading cells from $G_{0}$ to $S$ phase of cell cycle) and intracellular processing by endopeptidases generating this LDGF is an attractive field for further investigation.

Against this hypothesis stands the fact that at least theoretically limited proteolysis in position 112-113 aa of hCRP should generate a hCRP fragment no bigger than 9-10 kD (hCRP is $23.4 \mathrm{kD} ; 113-193$ is an 80 -aa long sequence). Our data documented that the purified LDGF was $17-18 \mathrm{kD}$ on SDSPAGE. Therefore, the LDGF may contain only partial homology to hCRP. This homology possibly exists in its $\mathrm{NH}_{2}$-terminal part that contains a LIM motif identical to the second zinc-finger of hCRP. Alternatively, LDGF and hCRP could be generated by the same gene using different promoters or alternative splicing as exemplified by the steroidogenic factor 1 (SF-1), an orphan nuclear receptor and the embryonal long term repeat-binding protein (ELP) (43). ELP possesses 78 additional aa in the $\mathrm{NH}_{2}$-terminal region and 57 different aa in the $\mathrm{COOH}$-terminal region, whereas SF-1 contains 131 additional aa in the $\mathrm{COOH}-$ terminal region. There also exists 330 common aa between SF1 and ELP. It is noteworthy that SF-1 possesses a zinc-finger and stimulates the expression of steroidogenic enzymes (43) as well as is also essential for adrenal and gonadal development (43) and sexual differentiation (44). In contrast, the function and role of the ELP is still unclear $(43,44)$.

In conclusion, our data partially identified the LDGF for human uterine smooth muscle cells and documented a threeto sixfold higher expression of LDGF mRNA in leiomyoma compared with adjacent myometrium. We conclude that LDGF is probably the major mitogen for smooth muscle cells in uterine leiomyomas.

\section{Acknowledgments}

The authors would like to thank Gilles Frenette for excellent technical assistance; Dr. Claude Lazure for the peptide sequencing and Dr. Hugh Bennett for peptide synthesis; Drs. Diogenes Cloutier, Pierre Dupont, Jacques Mailloux, Jacques Rioux, Marc Villeneuve, Michel Marois, and Rodolphe Maheux, Departments of Ob/Gyn and Pathology, Laval University for providing the tissue specimens; and Drs. G. Pelletier and F. Labrie for many helpful discussions regarding this work.

This work was supported by a grant from the Medical Research Council (MRC) of Canada to Michael Koutsilieris. M. Koutsilieris is a Scholar Chercheur-Boursier of the Fonds de la Recherche en Sante du Quebec-F.R.S.Q.

\section{References}

1. Pantazis, C. G., and E. F. Howard. 1987. Metastatic-stimulating activity in mouse uterus. Biol. Reprod. 36:701-708.

2. Maharajan, P., G. Paino, F. Rosato, N. Mirabella, G. Pelagalli, and V. Maharajan. 1988. Influence of mouse uterus on the metastatic patterns of tumor cells. Cancer Lett. 43:33-36.

3. Beck, C. A., and C. W. Garner. 1989. Characterization and estrogen regulation of growth factor activity from uterus. Mol. Cell. Endocrinol. 63:93-101.

4. Milner, P. G., Y. S. Li, R. M. Hoffman, C. M. Kodner, N. R. Siegel, and T. F. Deuel. 1989. A novel $17 \mathrm{kD}$ heparin-binding growth factor (HBGF-8) in bovine uterus: purification and $\mathrm{N}$-terminal amino acid sequence. Biochem. Biophys. Res. Commun. 165:1096-1103.

5. Simmen, R. C. M., Y. Ko, X. H. Liu, M. H. Wilde, W. F. Pope, and F. A.
Simmen. 1988. A uterine cell mitogen distinct from epidermal growth factor in porcine uterine fluids: characterization and partial purification. Biol. Reprod. 38:551-561.

6. Brigstock, D. R., R. B. Heap, P. J. Barker, and K. D. Brown. 1990. Purification and characterization of heparin-binding growth factors from porcine uterus. Biochem. J. 266:273-282.

7. Koutsilieris, M. 1989. Human uterus-derived growth substances for rat bone cells and fibroblasts. Am. J. Obstet. Gynecol. 161:1313-1336.

8. Koutsilieris, M. 1990. Uterus-derived growth substances: possible implications for human uterus physiology and pathophysiology. In Vivo (Athens) 4:4548.

9. Koutsilieris, M., and J. Michaud. 1990. Characterization of human uterusderived growth substances. In Vivo (Athens). 4:161-166.

10. Koutsilieris, M., J. Michaud, and A. Nikolis. 1990. Preferential mitogenic activity for myoblast-like cells can be extracted from leiomyoma tissues. Am. J. Obstet. Gynecol. 163:1665-1670.

11. Koutsilieris, M., D. Elmeliani, G. Frenette, and R. Maheux. 1992. Leiomyoma-derived growth factors for smooth muscle cells. In Vivo (Athens). 6:579584.

12. Pollard, J. W. 1990. Regulation of polypeptide growth factor synthesis and growth factor-related gene expression in the rat and mouse uterus before and after implantation. J. Reprod. Fertil. 88:721-73.

13. Beck, C. A., and C. W. Gardner. 1989. Characterization and estrogen regulation of growth factor activity from uterus. Mol. Cell. Endocrinol. 63:93101.

14. Chegini, N., C. V. Rao, N. Wakim, and J. Sanfilippo. 1986. Binding of ${ }^{125}$ I-epidermal growth factor in human uterus. Cell Tissue Res. 246:543-548.

15. Lumsden, M. A., C. P. West, T. Brandley, L. Rumgay, and D. T. Baird. 1988. The binding of epidermal growth factor to the human uterus and leiomyomata in women rendered hypooestrogenic by continuous administration of an LHRH agonist. Br. J. Obstet. Gynecol. 95:1299-1304.

16. Tommola, P., F. Pekonen, and E. M. Rutanen. 1989. Binding of epidermal growth factor and insulin-like growth factor I in human myometrium and leiomyomata. Obstet. Gynecol. 74:658-662.

17. Ghahary, A., and L. J. Murphy. 1989. Uterine insulin-like growth factorI receptors: regulation by estrogen and variation throughout the estrous cycle. Endocrinology. 125:597-604.

18. Wordinger, R. J., A. E. Moss, T. Lockard, D. Gray, I. F. C. Chang, and T. L. Jackson. 1992. Immunohistochemical localization of basic fibroblast growth factor within mouse uterus. J. Reprod. Fertil. 96:141-152.

19. Fayed, Y. M., G. C. M. Tsibris, P. W. Langenberg, and A. L. Robertson, Jr. 1989. Human uterine leiomyoma cells: binding and growth responses to epiderma growth factor, platelet-derived growth factor, and insulin. Lab. Invest. 60:30-37.

20. Rossi, M. J., N. Chegini, and B. J. Masterson. 1992. Presence of epidermal growth factor, platelet-derived growth factor, and their receptors in smooth muscle cells in vitro. Endocrinology. 130:1716-27.

21. Mendoza, A. E., R. Young, S. H. Orkin, and T. Collins. Increased plateletderived growth factor A-chain expression in human uterine smooth muscle cells during the physiologic hypertrophy of pregnancy. Proc. Natl. Acad. Sci. USA 87:2177-2181.

22. Das, S. K., K. C. Flanders, G. K. Andrews, and S. K. Dey. 1992. Expression of transforming growth factor- $\beta$ isoforms in mouse uterus: analysis of the periimplantation period and effects of ovarian steroids. Endocrinology. 133:3459-66.

23. Huynh, H. T., and M. Pollak M. 1993. Insulin-like growth factor I gene expression in the uterus is stimulated by tamoxiphen and inhibited by the pure antiestrogen ICI 182780. Cancer Res. 53:5585-5588.

24. Hoppener, J. W. M., S. Mosselman, P. J. M. Roholl, C. Lambrechts, R. J. C. Slebos, P. de Pagter-Holthuizen, C. J. M. Lips, H. S. Jansz, and J. S. Sussenbach. 1988. Expression of insulin-like growth factor-I and -II genes in human smooth muscle tumours. EMBO (Eur. Mol. Biol. Org.) J. 7:1379-1385.

25. Rein, M. S., A. J. Friedman, M. R. Pandian, and L. J. Heffner. 1990. The secretion of insulin-like growth factors I and II by explant cultures of fibroids and myometrium from women treated with a gonadotropin-releasing hormone agonist. Obstet. Gynecol. 76:388-394.

26. Vollenhoven, B. J., A. C. Herington, and D. L. Healy. 1993. Messenger Ribonucleic acid expression of the insulin-like growth factors and their binding proteins in uterine fibroids and myometrium. J. Clin. Endocrinol. Metab. 76:1106-1110.

27. Boehm, K. D., M. Daimon, I. G. Gorodeski, L. A. Sheehan, W. H. Utiah, and J. Allan. 1990. Expression of the insulin-like and platelet-derived growth factor genes in human uterine tissues. Mol. Reprod. Dev. 27:93-101.

28. Matsuo, O., H. Fukao, S. Izaki, C. Matsuo, and S. Ueshima. 1989. Production and characterization of single-chain tissue plasminogen activator by an established cell line from human uterine muscle. Cell Struct. Funct. 14:45-60.

29. Sourla, A., Reyes-Moreno, C., and M. Koutsilieris. 1995. Characterization of KW smooth muscle-like human myometrial cells. Anticancer Res. 112:18871892. 
30. Laemmli, U. K. 1970. Cleavage of structural proteins of the head of bacteriophage T4. Nature (Lond.). 227:680-685.

31. Koutsilieris, M., S. A. Rabbani, and D. Goltzman. 1986. Selective osteoblast mitogens can be extracted from prostatic tissues. Prostate. 9:109-115.

32. Koutsilieris, M., S. A. Rabbani, H. P. J. Bennett, and D. Goltzman. 1987. Characteristics of the prostate-derived growth factors for cells of the osteoblast phenotype. J. Clin. Invest. 80:941-946.

33. Lazure, C., H. S. Saayaman, R. J. Naude, W. Oelofsen, and M. Chretien 1989. Otrich MSEL-neurophysin belongs to the class of the two-domains 'big neurophysins as indicated by complete amino acid sequence of the neurophysins copeptin. Int. J. Pept. Protein Res. 33:46-58.

34. Koutsilieris, M., F. Grondin, and J. G. Lehoux. 1992. The expression of mRNA for glucocorticoid receptor gene and the glucocorticoid receptors detected in PA-III rat prostate adenocarcinoma cells. Anticancer Res. 12:899-904.

35. Liebhaber, S. A., J. G. Emery, M. Urbanek, X. Wang, and N. E. Cooke. 1990. Characterization of a human cDNA encoding a widely expressed and highly concerved cysteine-rich protein with an unusual zinc-finger motif. Nucleic Acids Res. 18:3871-3879.
36. Biro, J. C. 1986. Estrogen-induced proteins: a new class of regulatory substances. Med. Hypotheses. 19:199-228.

37. Sibarsku, D. A. 1978. Estrogen induction of growth factor specific for hormone-responsive mammary, pituitary, and kidney tumor cells. Proc. Natl. Acad. Sci. USA. 75:3786-3790.

38. Koutsilieris, M. 1992. Pathophysiology of the uterine leiomyomas. Biochem. Cell Biol. 70:272-278.34.

39. Birkenmeier, E. W., and J. I. Gordon. 1986. Developmental regulation of a gene that encodes a cysteine-rich intestinal protein and maps the murine immunoglobulin heavy chain locus. Proc. Natl. Acad. Sci. USA. 83:2516-2520.

40. Wang, X., G. Lee, S. A. Liebhaber, and N. E. Cooke. 1992. Human cystein-rich protein. A member of the LIM/double-finger family displaying coordinate serum induction with $c$-myc. J. Biol. Chem. 267:9176-9184.

41. Boehm, T., L. Foroni, M. Kennedy, and T. H. Rabbitts. 1990. The rhombotin gene belongs to a class of transcription factors with a potential novel protein dimerization motif. Oncogene. 5:1103-1105.

42. Nalik, P., M. Panayotova-Heirmann, and O. Pongs. 1989. Characterization of an estradiol-stimulated mRNA in the brain of adult male rats. Mol. Cell. Endocrinol. 62:235-242. 